\title{
Nadzór nad poziomem nawonienia paliw gazowych w świetle obowiązujących uregulowań prawnych i normatywnych
}

\begin{abstract}
Z procesem nawonienia paliw gazowych nieodłącznie związany jest problem nadzoru nad nim, czyli kwestia kontroli poziomu nawonienia gazu. Zgodnie z regulacjami prawnymi standardem jakościowym paliw gazowych obowiązującym w tym obszarze jest intensywność zapachu gazu, gwarantująca bezpieczeństwo jego użytkowania. Na podstawie aktualnych uregulowań prawnych i normatywnych przedsiębiorstwa energetyczne nadzorujące proces nawaniania opracowują własne, wewnętrzne procedury kontroli poziomu czy stopnia nawonienia paliw gazowych. Obowiązuje zasada, że stężenie środka nawaniającego w miejscu jego dozowania powinno być dobrane w taki sposób, aby zagwarantować końcowemu odbiorcy intensywność zapachu gazu w stopniu „wyraźnie wyczuwalnym”.
\end{abstract}

Słowa kluczowe: poziom nawonienia, kontrola nawonienia, krzywa zapachowa.

\section{Supervision of the level of odorization of gaseous fuels in the light of the applicable normative and legal regulations}

\begin{abstract}
The process of gas odorization is inherently related to the problem of its supervision or gas odorization level control. According to the regulations, the applicable standard for gas quality is the gas odor intensity, guaranteeing its safety use. Based on current legislation and standards, power companies supervising the odoration process, have to develop their own internal control procedures for the level or degree of gas odorization. The principle is that the concentration of the odorant added to the pipeline should be adjusted to ensure that at the final gas consumer the degree of gas intensity is "clearly perceptible".
\end{abstract}

Key words: odorization level, odorization monitoring, odor intensity curve.

\section{Parametry kontrolne w procesie nawaniania paliw gazowych w świetle uregulowań prawnych i normatywnych}

Zgodnie z obowiązującymi regulacjami prawnymi i normatywnymi [9-11, 13] zapewnienie bezpieczeństwa użytkowania paliw gazowych wymaga zagwarantowania mieszaninie gazu z powietrzem odpowiedniej jakości zapachu, uzyskiwanej w procesie jego nawaniania. Parametrem kontrolnym procesu nawaniania jest zatem intensywność zapachu nawonionego paliwa gazowego [10, 13]. Szczegółowy sposób prowadzenia kontroli jakości paliw gazowych, w tym również intensywności ich zapachu, określają rozporządzenia i normy krajowe [9-11, 13], instrukcje ruchu i eksploatacji sieci [3], taryfa dla usług przesyłania paliw gazowych [7], a w końcu wewnętrzne procedury przedsiębiorstw nadzorujących proces nawaniania.
Podstawowym aktem prawnym określającym specyfikację parametrów jakościowych krajowych gazów ziemnych jest rozporządzenie Ministra Gospodarki w sprawie szczegółowych warunków funkcjonowania systemu gazowego z 2010 roku [13]. W kwestii nawaniania paliw gazowych oraz jego kontroli rozporządzenie ustala, że adekwatnym parametrem jakościowym paliw gazowych przesyłanych sieciami dystrybucyjnymi jest intensywność ich zapachu $[13, \S 38.3]$, która powinna być kontrolowana co najmniej raz na dwa tygodnie $[13, \S 38.7]$ dla mieszaniny gazu z powietrzem o ściśle określonej zawartości gazu.

Przedsiębiorstwo energetyczne ma obowiązek prowadzenia bieżącej kontroli parametrów jakościowych gazu, w tym 
również intensywności jego zapachu, w sposób umożliwiający prawidłowe rozliczenie użytkowników systemu gazowego [13, § 39].

W obszarze normalizacyjnym wymogi co do jakości gazów ziemnych w sieci dystrybucyjnej określają normy PN-C04750:2011, PN-C-04751:2011 i PN-C-04753:2011 [9-11].

Zgodnie z zapisami normy PN-C-04751:2011 [10] jedną z wielkości zalecanych do wykorzystania w ocenie jakości gazu w sieci przesyłowej jest zawartość środka nawaniającego, a adekwatnym parametrem określającym jakość gazu dostarczanego odbiorcom z sieci dystrybucyjnej jest intensywność jego zapachu, którą należy sprawdzać węchowo dla mieszaniny gazu z powietrzem, w której stężenie gazu wynosi 20\% jego dolnej granicy wybuchowości. Z kolei oznaczenia zawartości środka nawaniającego w gazie należy wykonywać metodami opisanymi w normie PN-EN ISO 19739:2010 [12] lub metodą alternatywną, pod warunkiem, że niepewność uzyskanych wyników nie będzie większa niż ta, którą obarczone są wyniki uzyskane przy użyciu metod opisanych normą [12], a stosowane analizatory będą regularnie wzorcowane.

Norma PN-C-04751:2011 przy wskazywaniu kryteriów wyboru wielkości umożliwiających ocenę jakości gazu pozostawia dobrowolność wyboru wykonującym pomiary i uzależnia dobór tych wielkości od przeznaczenia oceny [10, pkt. 5.3].

Szczegółowe wymagania w stosunku do jakości paliw gazowych dostarczanych odbiorcom komunalnym i domowym oraz wartości parametrów charakteryzujących jakość gazów ziemnych stosowanych w przemyśle określa norma PN-C04753:2011 [11, pkt. 4]. Zgodnie z jej zapisami nawonienie gazu ma umożliwiać wykrycie jego niekontrolowanych upływów z sieci dystrybucyjnej, instalacji i urządzeń gazowych.

Podobnie jak w poprzednio przytoczonych dokumentach, zgodnie $\mathrm{z}$ danymi przedstawionymi $\mathrm{w}$ tablicy 1 PN-C-04753:2011 [9], parametrem gwarantującym odpowiednie nawonienie paliw gazowych jest intensywność zapachu gazu, określana węchowo metodami odorymetrycznymi. PN-C-04753:2011 [11] dopuszcza jednak możliwość zastąpienia pomiarów odorymetrycznych zapachu gazu pomiarami stężenia środka nawaniającego w gazie, pod warunkiem, że dla gazu rozprowadzanego z danej instalacji do nawaniania jest znana i udokumentowana korelacja pomiędzy intensywnością zapachu gazu a stężeniem środka nawaniającego w gazie oraz badania intensywności zapachu gazu u odbiorców prowadzi się z częstotliwością nie mniejszą niż raz na 14 dni.

Wszystkie powyższe zalecenia odnośnie kontroli poziomu nawonienia paliw gazowych znalazły swoje odzwierciedlenie w standardach technicznych Izby Gospodarczej Gazownictwa: ST-IGG-0702:2012 do ST-IGG-0705:2012 [14-17]. Również zgodnie z wymogami tych standardów (ST-IGG-0702:2012 [14] i ST-IGG-0704:2014 [16]),,instalacja do nawaniania powinna zapewnić takie dozowanie środka nawaniającego, aby uzyskać u odbiorcy wymaganą intensywność zapachu I = 2" (stopień intensywności według pięciostopniowej skali intensywności zapachu równoznaczny z terminem ,zapach wyraźnie wyczuwalny”). Według tego zapisu podstawowym parametrem kontrolnym poziomu nawonienia paliw gazowych jest stopień intensywności zapachu gazu nawonionego mierzony za pomocą metod węchowych.

Przytoczone powyżej regulacje prawne i normatywne, jak również zapisy standardów technicznych zgodnie potwierdzają, że parametrem świadczącym o odpowiednim poziomie nawonienia paliw gazowych (także parametrem opisującym jakość paliw gazowych w sieci dystrybucyjnej) jest intensywność ich zapachu, którą można określić jedynie metodą węchową. Jest to jednak metoda na tyle subiektywna i trudna do stosowania w rutynowych kontrolach, że w krajowym gazownictwie przy kontrolnych pomiarach poziomu nawonienia zastępuje się ją analitycznymi metodami pomiaru stężenia środka nawaniającego w gazie [3, 17]. Zgodnie z zapisami PN-C-04751:2011 [10] również stężenie związków nawaniających może być wskaźnikiem oceny prawidłowości przebiegu procesu nawaniania paliw gazowych, a więc parametrem istotnym dla bezpieczeństwa ich użytkowania. Jednak kontrola stężenia środków nawaniających może być stosowana alternatywnie do pomiarów intensywności zapachu gazu w sieci dystrybucyjnej jedynie pod pewnymi warunkami $[11,16]$.

Należy zaznaczyć, że wśród ustandaryzowanych metod kontroli nawonienia paliw gazowych (ZN-G-5001:2001 [18]) wyróżnia się trzy metody, a mianowicie:

- pomiar stopnia intensywności zapachu nawonionego paliwa gazowego,

- pomiar zawartości (stężenia) środka nawaniającego w paliwie gazowym,

- obliczanie zużycia środka nawaniającego w instalacji nawaniającej.

\section{Sposoby kontroli nawonienia paliw gazowych stosowane w krajowym systemie gazowniczym}

Obecnie za prowadzenie i nadzorowanie procesu nawaniania gazów ziemnych na znacznym obszarze kraju odpowiedzialna jest Polska Spółka Gazownictwa Sp. z o.o., pełniąca funkcję największego krajowego operatora systemu dys- trybucyjnego, którego kluczowym zadaniem jest bezpieczny transport paliw gazowych siecią dystrybucyjną bezpośrednio do odbiorców końcowych oraz sieci innych operatorów lokalnych. Obowiązek ten wynika z zapisów rozporządzenia Mini- 
stra Gospodarki z dnia 2 lipca 2010 roku w sprawie szczegółowych warunków funkcjonowania systemu gazowego [13]. Zgodnie z obowiązującą od stycznia 2015 roku taryfą dla usług przesyłania paliw gazowych GAZ-SYSTEM S.A. [7] nawanianie gazu może być również realizowane (OGP) jako usługa odpłatna, wchodząca w zakres tzw. usług dodatkowych, wykonywanych przez operatora sieci przesyłowej na zamówienie.

Przyjęte przez PSG Sp. z o.o. parametry jakościowe paliw gazowych w zakresie bezpieczeństwa ich użytkowania, określane intensywnością zapachu gazu, podano w Instrukcji Ruchu i Eksploatacji Sieci Dystrybucyjnej (IRiESD zatwierdzona decyzją Prezesa Urzędu Regulacji Energetyki z dnia 16 lutego 2015 roku - DRR-4323-8(10)/2014/2015/AKa1) [3]. Zasady i sposoby prowadzenia kontroli nawonienia gazów ziemnych sprecyzowane zostały natomiast w wewnętrznej procedurze przedsiębiorstwa, wdrożonej do powszechnego stosowania $\mathrm{w}$ roku bieżącym. W drugim zaś przypadku (OGP) sposób rozliczenia usługi, z uwzględnieniem zasad jej realizacji oraz ustalania poziomu nawonienia, zawarty jest $\mathrm{w}$ odpowiednich umowach o świadczeniu usługi nawaniania paliwa gazowego. W umowach tych strony określają warunki techniczne prowadzenia kontroli nawonienia paliw gazowych, stanowiącej podstawę rozliczenia usługi.

Nowo obowiązująca w obszarze OSD procedura prowadzenia nadzoru nawonienia paliw gazowych wprowadza pojęcia strefy i obszaru nawaniania - jako wydzielonych fragmentów systemu dystrybucyjnego, dla których należy prowadzić okresowe kontrole nawonienia gazów nimi rozprowadzanych [4]. Oceny poziomu nawonienia należy dokonywać, opierając się na wyznaczonych krzywych zapachowych gazów ziemnych $z$ grup $E, L_{s} i L_{w}$. Podstawą ocen są pomiary analityczne stężenia środka nawaniającego $\mathrm{w}$ gazie wykonywane przez laboratoria badawcze (metoda chromatografii gazowej), służby eksploatacyjne (metoda detekcji bezpośredniej) lub procesowe analizatory chromatograficzne THT (wykorzystujące metodę chromatografii gazowej). Oprócz metod instrumentalnych kontroli stężenia środka nawaniającego przewidziana jest również ankietyzacja zapachu paliwa gazowego, wykonywana u odbiorcy.

Dominującą metodą nadzoru procesu nawonienia paliw gazowych jest pomiar stężenia środka nawaniającego $\mathrm{w}$ gazie. Istniejące i stosowane $\mathrm{w}$ praktyce gazowniczej instrumentalne metody takiego pomiaru można sklasyfikować pod względem typu aparatury pomiarowej, sposobu prowadzenia pomiaru czy sposobu detekcji. Z punktu widzenia praktycznych zastosowań rozróżnia się metody, w których próbkę wprowadza się do układu pomiarowego automatycznie w sposób ciągły, i metody, w których próbkę wprowadza się do układu pomiarowego innymi metodami w ustalonym reżimie czasowym.
Praktykowane obecnie w krajowym gazownictwie oznaczenia analityczne, których celem jest dostarczenie ilościowych informacji o przebiegu procesu nawaniania, można podzielić na dwie główne kategorie, uwzględniające sposób prowadzenia pomiaru:

1) pomiary w trybie off-line, do których zaliczyć należy pomiary laboratoryjne wykonywane $\mathrm{z}$ dala od gazociągu, a tym samym od miejsca poboru próbki (z użyciem próbki pochodzącej z tzw. strumienia procesowego - strumienia badanego gazu);

\section{OFF-LINE}

LABORATORIUM CENTRALNE

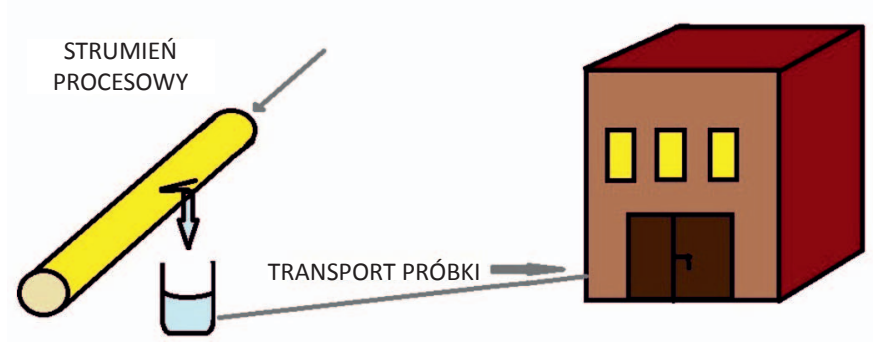

Rys. 1. Schemat zasady prowadzenia pomiarów w systemie off-line [1]

2) pomiary w trybie on-line, których szczególnym przypadkiem jest monitoring (tj. analiza procesowa); pomiary te związane są $\mathrm{z}$ wykonywaniem analizy $\mathrm{w}$ trakcie prowadzenia procesu przez urządzenia pomiarowe zainstalowane na stałe lub okresowo w miejscu pobierania próbek; próbka jest pobierana automatycznie (przy zachowaniu odpowiedniego reżimu czasowego) przez analizator.

\section{ON-LINE}

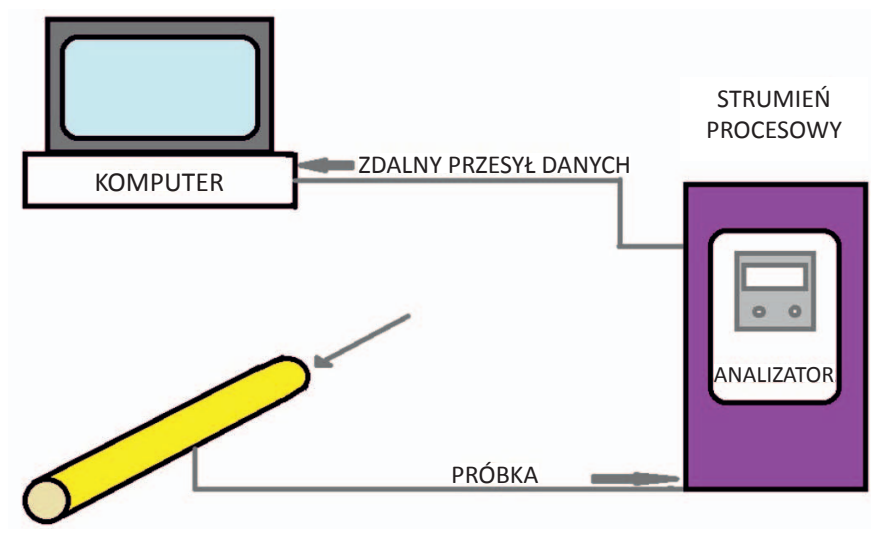

Rys. 2. Schemat zasady prowadzenia pomiarów w systemie on-line [1]

W obu przypadkach wykorzystywanych jest wiele rozwiązań technicznych. W pomiarach dokonywanych przez przyrząd pomiarowy umieszczony bezpośrednio przy gazociągu stosowane rozwiązania to: 
- pomiary ciągłe wykonywane bezpośrednio w strumieniu przepływającego gazu z użyciem automatycznych (samoczynnie pobierających próbkę gazu do analizy) analizatorów typu on-line o różnych klasach dokładności i wymagających różnych zestawów dodatkowego oprzyrządowania sprzętowego (umożliwiającego wizualizację i archiwizację danych pomiarowych itp.); wykonanie tych pomiarów nie wymaga obecności analityków, a wyniki przekazywane są zdalnie do odpowiednich centrów dyspozytorskich w postaci raportów okresowych,

- pomiary okresowe wykonywane z wymaganą prawnie częstotliwością dla próbek gazu pobranych przez analityka/operatora z gazociągu (najczęściej w miejscach poboru charakteryzujących się podobnymi parametrami jak w przypadku pomiarów wykonywanych metodą on-line) do analizatora chromatograficznego lub urządzenia wskaźnikowego - otrzymany wynik wymaga ręcznego opracowania w postaci stosownego raportu.

Pomiary prowadzone w trybie off-line wykonywane sa okresowo, a wynik pomiaru jest pomiarem wyrywkowym w procesie okresowej kontroli nawaniania paliw gazowych. $\mathrm{Z}$ kolei pomiary w trybie on-line mogą przebiegać w sposób ciągły bezpośrednio w strumieniu przepływającego gazu. Urządzenia działające w trybie on-line pracują w czasie rzeczywistym w cyklu całodobowym, dając możliwość prowadzenia stałej i bieżącej kontroli procesu nawaniania.

Należy podkreślić, że zgodnie z zapisami normatywnymi $[11,18]$, dopuszczającymi pomiar stężenia środka nawaniającego w gazie w celu oceny jakości gazu, oraz zapisami standardu IGG [17] - oznaczenia stężenia nawaniacza należy prowadzić metodami chromatograficznymi według wymagań PN-EN ISO 19739:2010 [12].

Z uwagi na konieczność zapewnienia podobnej dokładności pomiarów kontrolnych stężenia środka nawaniającego należy przy doborze urządzeń pomiarowych przeznaczonych do ich wykonywania uwzględnić urządzenia charakteryzujące się zbliżoną lub taką samą dokładnością wskazań. Oznacza to, że metrologicznie poprawne [8] jest stosowanie alternatywne przyrządów pomiarowych stężenia środka nawaniającego w gazie typu off-line (pomiary laboratoryjne) oraz on-line (urządzenia procesowe i przewoźne), o ile charakteryzują się one podobną dokładnością oznaczeń, a pomiar wykonywany jest metodą chromatografii gazowej (zgodnie z wymogami normy [12]).
Szczegółowe wymagania metrologiczne w stosunku do dokładności pomiarów stężenia środka nawaniającego w gazie są sprecyzowane $\mathrm{w}$ odpowiednich wewnętrznych procedurach kontroli nawonienia gazów OSD lub ewentualnie w umowie zawieranej pomiędzy podmiotami rozliczającymi usługę nawaniania paliw gazowych [4].

W ostatnich latach na popularności zyskują urządzenia pomiarowe mogące pracować on-line w warunkach obiektowych, przystosowane do przekazywania wyników pomiarów zdalnie, w czasie rzeczywistym [2]. Zgodnie $\mathrm{z}$ tą tendencją w gazownictwie coraz powszechniejsze staje się stosowanie chromatograficznych analizatorów on-line przeznaczonych do pomiarów stężenia THT w gazie, spełniających wymagania PN-EN ISO 19739:2010 [12]. Przez analizator on-line pracujący w warunkach obiektowych należy rozumieć tu urządzenie pomiarowe działające bezobsługowo w warunkach procesowych, w którym wszystkie czynności związane $\mathrm{z}$ analizą próbki (w tym także pobór próbki i zdalny przekaz wyniku pomiaru) odbywają się automatycznie. Tego typu pomiar (automatyczny w trybie on-line) jest ważnym elementem prowadzenia i monitorowania procesu nawaniania paliw gazowych, a jakość uzyskiwanych wyników pomiarów, przy zachowaniu odpowiednich warunków prowadzenia kontroli, może być porównywalna z jakością wyniku uzyskanego przy użyciu chromatografów laboratoryjnych.

Stosowane w praktyce gazowniczej chromatograficzne analizatory procesowe posiadają wbudowane niezależne systemy samoczynnego wzorcowania, pozwalające na wykonywanie pomiarów kalibracyjnych (tzw. wzorcowanie wewnętrzne) okresowo lub każdorazowo przed pomiarem właściwym. Jednakże dla kontroli właściwej pracy urządzeń procesowych niezbędne jest również wykonywanie wzorcowania zewnętrznego, np. poprzez pomiary referencyjne/ porównawcze.

Częstą praktyką jest także stosowanie analizatorów przewoźnych lub ręcznych urządzeń przenośnych, mogących wykonywać pomiary w trybie on-line. Takie urządzenia posiadają jednak wiele ograniczeń $\mathrm{z}$ uwagi na wykorzystanie w nich metody detekcji bezpośredniej. Pomiar wykonywany takim urządzeniem obarczony jest dużą niepewnością, a jego jakość zależy od obecności szeregu interferentów oraz od temperatury, w jakiej się go przeprowadza. Zgodnie ze standardem ST-IGG-0705:2012 [17] jest to jedynie pomiar orientacyjny.

\section{Zagrożenia wynikające z braku prowadzenia kontroli intensywności zapachu metodami odorymetrycznymi}

Powszechnie przyjęty schemat prowadzenia nadzoru nad stopniem nawonienia paliw gazowych, oparty w głównej mierze - a czasami jedynie - na pomiarach stężenia środka na- waniającego w gazie, niesie ze sobą wiele zagrożeń. Przede wszystkim wyeliminowanie z planu kontroli poprawnie wykonywanych pomiarów intensywności zapachu skutkuje uzy- 
skaniem wyników niezgodnych z wymogami prawnymi [13] oraz zaleceniami normatywnymi [9-11]. Należy tu zaznaczyć, że poprawnie wykonane pomiary intensywności zapachu, zgodne z obowiązującymi wymogami prawnymi i normatywnymi [9-11, 13], to pomiary wykorzystujące metodę odorymetryczną [5] (niezależnie od sposobu ich przeprowadzania) dla mieszaniny gazu z powietrzem o ściśle określonym stężeniu gazu - na poziomie $20 \%$ jego dolnej granicy wybuchowości. Nie można niestety do takich pomiarów zaliczyć ankietyzacji u odbiorców, wykonywanej na dodatek najczęściej przez osoby bez odpowiedniego przeszkolenia i zwykle ,przyzwyczajone” do zapachu środka nawaniającego. W tego typu ocenie zapachu ,gazu” - z założenia nie odnotowuje się, wymaganego przepisami [13], odpowiedniego stężenia gazu w mieszaninie z powietrzem, dla którego należy przeprowadzić ocenę.

Podsumowując przytoczone wcześniej zalecenia stosownych norm [18] i standardów [16], można dokonać podziału kontroli nawonienia paliw gazowych na kontrolę stopnia/poziomu nawonienia oraz kontrolę przebiegu samego procesu. Oba rodzaje kontroli są definiowane i realizowane w następujący sposób:

1) kontrola procesu nawonienia - ma na celu głównie kontrolę pracy urządzeń nawaniających i prowadzona jest zwykle poprzez pomiary stężenia środka nawaniającego w gazie, badania intensywności zapachu gazu u odbiorców (wykonywane zgodnie z opracowaną w tym celu procedurą) oraz pomiary zużycia środka nawaniającego w instalacji nawaniania, służące do weryfikacji stosowanej dawki środka nawaniającego;

2) kontrola stopnia nawonienia - ma na celu kontrolę jakości zapachu gazu u odbiorcy i zagwarantowanie mu bezpieczeństwa jego użytkowania; prowadzona jest poprzez odorymetryczne pomiary intensywności zapachu gazu wykonywane równolegle z pomiarami stężenia środka nawaniającego w gazie. Należy tu podkreślić, że prawidłowo przeprowadzona na tym poziomie kontroli końcowa ocena stopnia intensywności zapachu powinna uwzględnić przynajmniej dwie z poniższych metod:

a) pomiar stopnia intensywności zapachu gazu metodą bezpośrednią,

b) pomiar stopnia intensywności zapachu metodą profilu wrażliwości powonienia, c) stopień intensywności zapachu odczytany z krzywej zapachowej paliwa gazowego dla danego stężenia THT w badanym gazie. Stężenie THT w gazie należy określić metodą chromatografii gazowej według ST -IGG-0705:2012 [15] lub PN-EN ISO 19739:2010 [12].

W metodzie określonej w punkcie „c” (często wykorzystywanej w praktyce [4]) pomiar stężenia środka nawaniającego w gazie jest pomiarem pośrednim w ocenie intensywności zapachu. Zagrożeniem dla oceny intensywności zapachu gazu prowadzonej jedynie pośrednio poprzez pomiary stężenia środka nawaniającego jest nie tylko brak spełniania wymogów prawnych i normatywnych [9-11, 13], ale również, co gorsza, brak pełnej gwarancji zapewnienia użytkownikowi końcowemu bezpieczeństwa użytkowania dostarczanego paliwa.
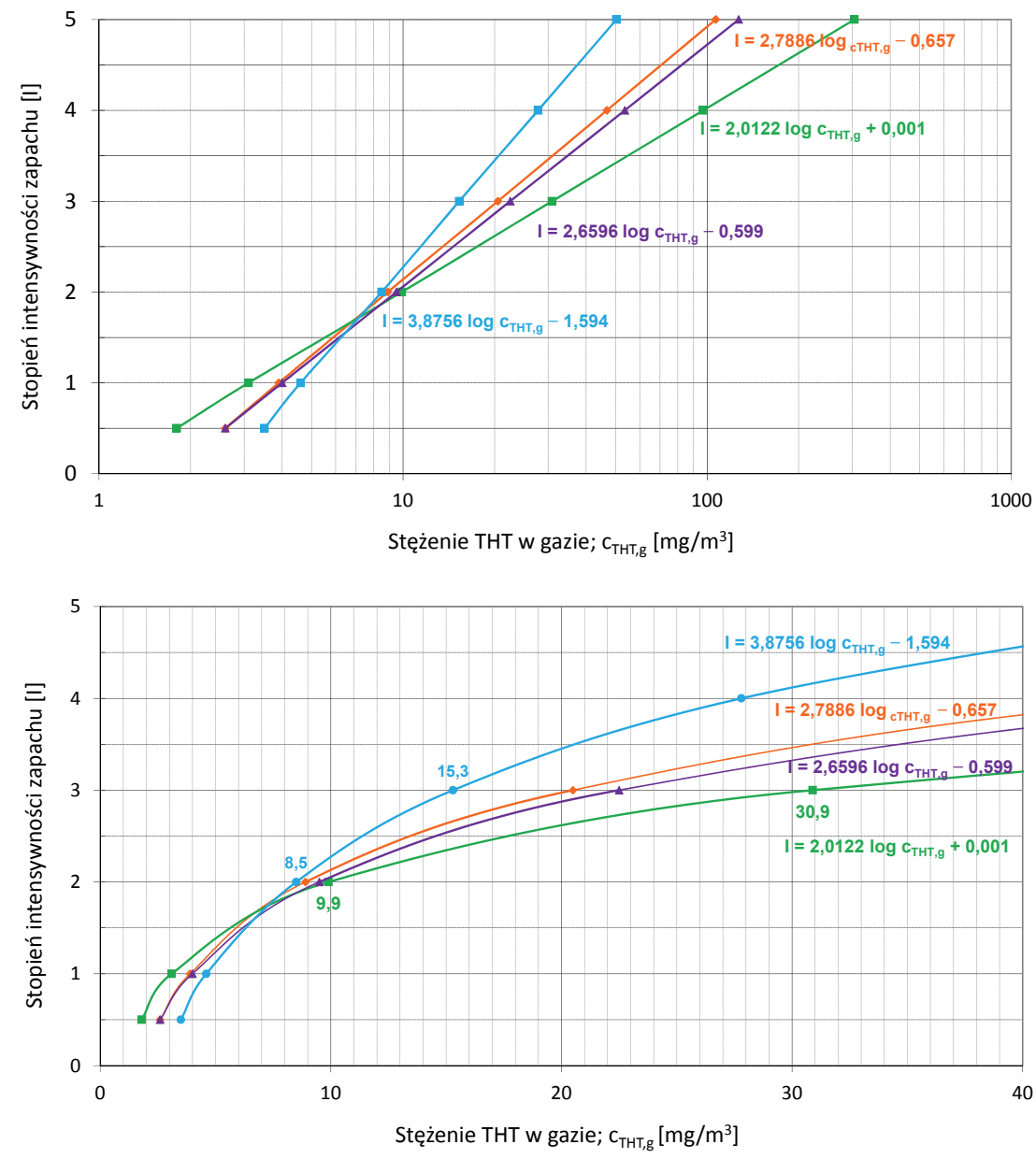

Rys. 3. Krzywe zapachowe gazu ziemnego wysokometanowego grupy E

Na rysunku 3 zobrazowano przebieg rzeczywistych krzywych zapachowych gazów ziemnych z grupy E, rozprowadzanych krajowymi sieciami dystrybucyjnymi. Gazy, dla których wyznaczono krzywe, różniły się składem, co odzwierciedlają wartości dolnej granicy wybuchowości (DGW). Wartości te mieściły się $\mathrm{w}$ granicach $4,87 \div 5,17 \mathrm{i}$ były niższe od wartości literaturowych [6]. Krzywe zostały wyznaczone przez pra- 
cowników Zakładu Nawaniania Paliw Gazowych INiG - PIB w latach 2001-2011. Określana na podstawie zamieszczonych krzywych zapachowych wartość minimalnego stężenia ostrzegawczego THT w gazie $\mathrm{MS}_{\mathrm{THT}}$ (najmniejsze stężenie środka nawaniającego $\mathrm{w}$ gazie gwarantujące jego mieszaninie z powietrzem zapach wyraźnie wyczuwalny $[11,13]$ o stopniu intensywności zapachu I = 2) jest jedynie wielkością „,wyjściową”, którą należy okresowo weryfikować w warunkach eksploatacyjnych (wielkość charakterystyczna dla danego odcinka sieci, okresowo zmienna w zależności od parametrów sieci i warunków otoczenia). Doświadczenia pracowników INiG - PIB wskazują, że dla wielu z badanych odcinków sieci gazowych dawkę środka nawaniającego, skorygowaną w wyniku okresowej weryfikacji wartości $\mathrm{MS}_{\mathrm{THT}}$, można obniżyć (na podstawie pomiarów intensywności zapachu gazu) od około 15\% do nawet $60 \% \mathrm{w}$ stosunku do stosowanej.

Brak weryfikacji minimalnego stężenia ostrzegawczego środka nawaniającego w gazie wykonywanej na bazie pomiarów intensywności zapachu gazu przyczynia się w znaczący sposób do prowadzenia procesu nawaniania gazów w sposób nieekonomiczny.

Intensywność zapachu gazu można określić jedynie metodą węchową, która w rutynowych kontrolach poziomu nawonienia zastępowana jest analitycznymi metodami pomiaru stężenia środka nawaniającego w gazie. Wobec wpływu wielorakich czynników na jakość i charakter zapachu nawonionego gazu, takich jak jego skład, parametry fizyczne, jak również parametry samej sieci gazowej, zauważono tu następujące zagrożenia:

- Przypisanie danej grupie gazu jednej uśrednionej dla danej grupy gazu krzywej zapachowej (literaturowej bądź wyznaczonej dla gazu o konkretnym składzie, co ma znaczenie w przypadku gazów krajowych) bez jej corocznej weryfikacji najczęściej prowadzi do otrzymania błędnych wartości intensywności zapachu gazu, uzyskiwanych na podstawie wyniku pomiaru stężenia odniesionego do tejże krzywej.

- Brak pomiarów intensywności zapachu gazu prowadzonych metodami odorymetrycznymi powoduje niezgodność z wymogami prawnymi w zakresie jakości gazów oraz brak potwierdzenia dostarczania odbiorcom gazu o wymaganych parametrach jakościowych (wyniki ankietyzacji nie mogą w żaden sposób być porównywane z rezultatami pomiarów odorymetrycznych, choćby z uwagi na fakt wykonywania oceny dla nieporównywalnych zawartości gazu w mieszaninie z powietrzem (brak zgodności jakości próbek do badań) czy stosowanie innych skal do oceny stopnia intensywności).

- Brak okresowej weryfikacji wartości minimalnego stężenia środka nawaniającego w gazie (zalecenia standar- du [16]), gwarantującego mieszaninie tego gazu z powietrzem uzyskanie zapachu wyraźnie wyczuwalnego (ostrzegawczego), która to wartość służy do wyznaczania dawki środka nawaniającego wprowadzanej do gazu, może przyczynić się w sposób znaczący do prowadzenia nieekonomicznego nawaniania gazów.

Określona analitycznie zawartość nawaniacza w gazie nie odzwierciedla w pełni, nawet mimo wykorzystania specjalistycznej aparatury pomiarowej i zaangażowania wysoko wykwalifikowanego personelu, rzeczywistej wartości intensywności zapachu gazu obecnego w powietrzu, która zależy nie tylko od stężenia nawaniacza w badanym gazie. $Z$ tego właśnie względu niezbędna jest okresowa kontrola zapachu gazu metodami węchowymi, np. poprzez pomiar jego intensywności metodą odorymetryczną. Analityczne metody kontroli nawonienia nie uwzględniają tzw. efektu synergicznego zapachu. Intensywność zapachu danej substancji nie jest cechą addytywną. Mieszanie dwóch substancji zapachowych o prawie identycznej intensywności zapachu może dawać efekt ujemny (tłumienie zapachu) i mieszanina będzie charakteryzować się niższą intensywnością zapachu od zapachu każdego z jej składników. Może wystąpić także efekt dodatni (jeden środek zapachowy wzmocni działanie drugiego środka) i wówczas zapach mieszaniny będzie bardziej intensywny, niż wynikałoby to ze stężeń zmieszanych środków zapachowych.

Dodatkowo same pomiary analityczne stężenia środka nawaniającego w gazie mają swoje ograniczenia. W pomiarach analitycznych związanych z poborem manualnym i/ lub transportem próbki dokładność wyniku uwarunkowana jest w zasadniczym stopniu dokładnością pobrania i przygotowania próbki do analizy. Badana próbka powinna być reprezentatywna dla całego strumienia gazu, a zarazem dostarczona do urządzenia pomiarowego z jak najmniejszą zwłoką czasową, która przekłada się na zmianę jej składu i czystość. Naprzeciw temu zagadnieniu wychodzą pomiary wykonywane w sposób on-line, niepozbawione również wad. W przypadku pomiarów prowadzonych w trybie on-line właściwe pobranie próbki jest także bardzo istotne dla prawidłowego wyniku analizy. Z tego względu analizatory on-line wyposażone są zwykle w odpowiednio zaprojektowane i wykonane układy pobierania próbek (moduł i linia poboru), które w warunkach minimalnego nadzoru i obsługi zapobiegają zmianom próbki. Do parametrów, których utrzymanie jest istotne (dla poprawności wyniku pomiaru) przy pobieraniu próbki do analizatora, należą zwłaszcza temperatura, ciśnienie, zawartość wilgoci, zapylenie czy zawartość zawiesin. W przypadku takich urządzeń niezwykle istotny jest zatem właściwy dobór reprezentatywnego punktu poboru próbki. 
Punkt poboru powinien bowiem zapewniać próbkę istotną statystycznie, co dotyczy wszystkich pomiarów stężenia środka nawaniającego w gazie, niezależnie od sposobu ich wykonywania.

Zgodnie z wcześniejszymi informacjami, powszechnie stosowana procedura kontroli nawaniania paliw gazowych w sieci dystrybucyjnej opiera się na pomiarach analitycznych stężenia THT w gazie prowadzonych w trybie on-line: z użyciem analizatorów procesowych oraz przenośnych urządzeń wskaźnikowych. Przeznaczeniem pomiarów wykonywanych w trybie off-line przez laboratoria gazownicze jest głównie okresowa weryfikacja wyżej wymienionych metod.

Każdy ze sposobów prowadzenia pomiarów kontrolnych nawaniania paliw gazowych metodami instrumentalnymi, stosowanych obecnie w krajowym przemyśle gazowniczym, ma swoje mocne i słabe strony, a więc i zagrożenia dla jakości uzyskiwanego wyniku.

Sposób kontroli off-line (pomiary laboratoryjne) cechuje duża dokładność i precyzja [8] wyników pomiarów, możliwość pełnego nadzoru nad stanem i sprawnością urządzenia pomiarowego czy też możliwość stosowania dowolnych metod analitycznych, programowalnych i archiwizowanych w pamięci urządzenia pomiarowego. Jednak pomiar kontrolny stężenia nawaniacza $\mathrm{w}$ gazie jest chwilowym pomiarem wyrywkowym w procesie okresowej kontroli nawaniania paliw gazowych. Ten rodzaj prowadzenia kontroli wiąże się ze wspomnianą już koniecznością transportu badanej próbki do laboratorium, a poprawność wyniku uzależniona jest od właściwego nadzoru nad przenoszeniem danych źródłowych do odpowiednich arkuszy zbiorczych bądź raportów okresowych. Wynik końcowy oznaczenia zależy od sposobu poboru, transportu i właściwego przygotowania próbki do analizy (w przypadku pomiarów stężenia THT w gazie zazwyczaj co najmniej dwie osoby uczestniczą w całym procesie pomiaru).

Pomiary wykonywane na obiekcie w wyznaczonym punkcie kontrolnym ( $\mathrm{z}$ użyciem analizatora przewoźnego lub przenośnego) cechuje prosta realizacja pomiaru stężenia określonego związku siarki w gazie, szybkie uzyskanie wyniku pomiaru oraz zwykle łatwa obsługa urządzeń pomiarowych. Wśród wad tego rodzaju pomiarów należy wymienić konieczność stosowania najprostszych metod pomiarowych, co pociąga za sobą zmniejszoną czułość urządzenia pomiarowego oraz konieczność obsługi urządzenia przez analityków lub „operatorów”, pobierających próbkę ręcznie. Wymagana jest zatem właściwa izolacja termiczna linii i/lub modu- łu poboru próbki dla zapewnienia odpowiedniej dokładności wyników pomiarów (warunek konieczny zwłaszcza zimą). Zwykle występuje również konieczność stabilizacji urządzenia przed wykonaniem pomiarów (wpływ wstrząsów mechanicznych na stabilność pracy sensora/detektora, który należy określić eksperymentalnie w badaniach wstępnych urządzenia pomiarowego). Pomiar kontrolny stężenia nawaniacza w gazie, podobnie jak w przypadku pomiarów laboratoryjnych, jest pomiarem wyrywkowym w procesie okresowej kontroli nawaniania paliw gazowych, wykonywanej z częstotliwością określoną przepisami prawnymi.

W przypadku stosowania urządzeń przenośnych wykorzystujących metodę detekcji bezpośredniej jakość oznaczeń (dokładność pomiaru) uzależniona jest od obecności niektórych składników gazu (wodór, metanol, inne związki siarki, nienasycone węglowodory), temperatury, w której wykonywany jest pomiar (co wymusza konieczność kalibracji urządzenia na obiekcie w miejscu prowadzenia pomiarów), jak również od liczby wykonywanych pomiarów.

Z kolei pomiary prowadzone on-line pozwalają uzyskać wyniki w czasie rzeczywistym w cyklu całodobowym i całorocznym, co daje możliwość stałej i bieżącej kontroli procesu nawaniania paliw gazowych oraz umożliwia zwiększony nadzór nad przebiegiem procesu nawaniania, poprawiający jego skuteczność i niezawodność. Niewątpliwą wadą takiego sposobu prowadzenia kontroli jest natomiast zmniejszona w stosunku do urządzeń laboratoryjnych dokładność i precyzja pomiarów oraz brak możliwości pełnego nadzoru nad stanem i sprawnością urządzenia, co może mieć bezpośrednie przełożenie na jakość uzyskiwanych wyników pomiarów.

Wymienione powyżej zalety automatycznych metod pomiarowych powodują, że metody te są bardzo użyteczne w pomiarach rutynowych i wpisane w schemat nadzoru nad poziomem nawonienia gazu w sieci dystrybucyjnej.

Porównując różne sposoby prowadzenia nadzoru analitycznego nad nawonieniem paliw gazowych, należy zauważyć, że niezwykle ważne jest ustanowienie jednolitych wymagań metrologicznych w stosunku do dokładności pomiarów stężenia środków nawaniających w gazie, z uwagi na zapewnienie możliwości porównywania wyników pomiarów wykonywanych w różnych miejscach i czasie. Jest to istotne również ze względu na zapewnienie podobnej dokładności pomiarów wykorzystujących różne przyrządy pomiarowe, dla których określono wymagania odpowiadające klasom dokładności.

\section{Podsumowanie}

Pomimo znacznej opłacalności ekonomicznej prowadzenia zdalnego monitoringu procesu nawaniania (efek- tem racjonalnej automatyzacji kontroli stężenia środka nawaniającego w gazie może być takie zmniejszenie kosztu 
jednostkowego analizy, które da około 10-krotne obniżenie całkowitych kosztów pracy związanych z wykonywaniem analiz kontrolnych), zapewniającego odpowiednią jego stabilność i powodującego znaczne obniżenie kosztów eksploatacji, nie może on, według obowiązujących wymogów prawnych, zastąpić metod pomiaru intensywności za- pachu paliw gazowych. Niestety wiele przemawia za tym, że w obecnej praktyce nadzoru nad stopniem nawonienia gazów pomiary te są znacząco ograniczone, a ich prowadzenie niezgodne $\mathrm{z}$ wymaganiami stosownego standardu, precyzującego sposoby ich wykonania metodami odorymetrycznymi [16].

Prosimy cytować jako: Nafta-Gaz 2016, nr 11, s. 953-960, DOI: 10.18668/NG.2016.11.09

Artykuł nadesłano do Redakcji 1.02.2016 r. Zatwierdzono do druku 26.10.2016 r.

Artykuł powstał na podstawie referatu zaprezentowanego na Konferencji Naukowo-Technicznej FORGAZ 2016 „Techniki i technologie dla gazownictwa - pomiary, badania, eksploatacja", zorganizowanej przez INiG - PIB w dniach 13-15 stycznia 2016 r. w Muszynie.

\section{Literatura}

[1] Callis B. J., Illman D. L., Kowalski B. R.: Process Analytical Chemistry. Anal. Chem. 1987, vol. 59, nr 9, s. 624A-637A.

[2] Holewa J., Szlęk M.: Ocena jakości gazów palnych. Nafta-Gaz 2013, nr 6, s. 450-454.

[3] Instrukcja Ruchu i Eksploatacji Sieci Dystrybucyjnej. Polska Spółka Gazownictwa Sp. z o.o., Warszawa, luty 2015; http:/ www.psgaz.pl/web/guest/iriesd (dostęp: październik 2015).

[4] Laszuk W.: Problematyka wyznaczania i aktualizacji ORCS oraz obszarów nawaniania z wykorzystaniem urzadzeń do zdalnego pomiaru parametrów jakościowych. [W:] INiG - PIB: Techniki i technologie dla gazownictwa - pomiary, badania eksploatacja. Konferencja Naukowo-Techniczna FORGAZ 2016. Materiały konferencyjne. Muszyna 13-15.01.2016, Kraków 2016, s. 185-201.

[5] Lisman Sz., Huszał A.: Dostosowanie prototypu przystawki odorymetrycznej sprzężonej z chromatografem gazowym do badania zapachowej jakości gazów. Nafta-Gaz 2015, nr 3, s. $190-194$.

[6] Pritsching K.: Odorierung. Wyd. 3, Vulkan Verlag 2010.

[7] Taryfa dla usług przesyłania paliw gazowych $\mathrm{nr} 9$. Warszawa, styczeń 2015; http://www.gaz-system.pl/strefa-klienta/ taryfa/taryfa-i-stawki-oplat/ (dostęp: październik 2015).

[8] Trojanowicz M.: Automatyzacja w analizie chemicznej. Warszawa, Wydawnictwa Naukowo-Techniczne, 1992.

\section{Akty prawne i normatywne}

[9] PN-C-04750:2011 Paliwa gazowe. Klasyfikacja, oznaczenia $i$ wymagania.

[10] PN-C-04751:2011 Gaz ziemny. Ocena jakości.

[11] PN-C-04753:2011 Gaz ziemny. Jakość gazu dostarczanego odbiorcom z sieci dystrybucyjnej.

[12] PN-EN ISO 19739:2010 Gaz ziemny. Oznaczanie związków siarki metoda chromatografii gazowej.

[13] Rozporządzenie Ministra Gospodarki z dnia 2 lipca 2010 r. w sprawie szczegółowych warunków funkcjonowania systemu gazowego (Dz. U. z 2010 r. Nr 133, poz. 891 z późn. zm., tj. Dz. U. z 2014 r. poz. 1059).

[14] ST-IGG-0702:2012 Nawanianie paliw gazowych. Wymagania dotyczace postepowania ze środkami nawaniajacymi oraz ich przechowywania i transportu.

[15] ST-IGG-0703:2012 Nawanianie paliw gazowych. Instalacje do nawaniania paliw gazowych.

[16] ST-IGG-0704:2014 Nawanianie paliw gazowych. Kontrola nawaniania paliw gazowych metodami odorymetrycznymi.

[17] ST-IGG-0705:2012 Nawanianie paliw gazowych. Metody oznaczania zawartości tetrahydrotiofenu (THT).

[18] ZN-G-5001:2001 Gazownictwo. Nawanianie paliw gazowych Wymagania ogólne dotyczace nawaniania gazu ziemnego.

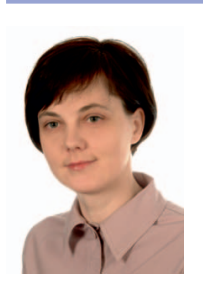

Dr Anna HUSZAŁ

Adiunkt; kierownik Zakładu Nawaniania Paliw Gazowych.

Instytut Nafty i Gazu - Państwowy Instytut Badawczy ul. Lubicz 25 A

31-503 Kraków

E-mail:anna.huszal@inig.pl 